\title{
The Leadership Practices of the South African Primary School Principals in Promoting Shared Decision Making
}

\author{
Shuti Steph Khumalo \\ University of South Africa, Pretoria, Gauteng, \\ Republic of South Africa, ooor \\ E-mail: ekhumass@unisa.ac.za
}

\begin{abstract}
Decision-making is a very critical aspect of management in the schooling environment. The purpose of this chapter was to investigate the role of primary school principals in engaging role players (particularly teachers) in decision-making in South Africa. Before the democratic dispensation in South Africa, decision-making was predominantly top down. This means that school leadership and principals in particular, made most decisions on their own and teachers were expected to implement these decisions without asking questions. The current study was conducted in the Waterberg Education Department, which is one of the education districts in South Africa. A descriptive research method was used and one hundred and seventy questionnaires were administered to teachers. The study revealed that the majority of principals do promote shared decision-making. This is demonstrated by the fact that the findings further indicate that principals create opportunities for decision-making, they provide feedback and expect engagement of the feedback and allow the views of stakeholders in the work allocation process.
\end{abstract}

Keywords: Engagement Opportunities, High Involvement, Job Involvement, Participatory Involvement, Parallel Suggestion, Principals, Leadership, Leadership Processes, Decision Making 
This is a limited preview of the chapter.

To read the full-text chapter, get access by purchasing this chapter or consider buying the complete book. If your library has subscription to EBSCOhost, the chapter including other chapters of the book can be accessed through your library.

This chapter is a part of the book, 'Innovations in Educational Leadership and Continuous Teachers' Professional Development' ISBN (paperback): 978-8I-948483-2-5; ISBN (ebook): 978-8I' $948483-3-2$

Book DOI: https://dx.doi.org/ro.46679/isbn9788194848325 Chapter DOI: https://dx.doi.org/IO.46679/isbn978819484832507 
sufficient. Despite this finding, the majority of primary school principals seem to create opportunities where teachers are involved in the decision-making processes.

\section{Conclusion}

Through a literature study it was discovered that traditionally, principals relied on the top-down style of leadership. This system of leadership was exclusive in nature because principals were the sole decisionmakers. It was argued that principals naturally expected their orders to be followed with relatively little discussion. The purpose of this study was to investigate whether primary school principals engage teachers in decisionmaking processes. Evidence gathered through the questionnaires indicates that the majority of primary school principals seem to create opportunities where teachers are involved in decision-making processes. It can thus be concluded that to a significant extent, primary school principals do promote shared decision-making because they involve teachers.

\section{References}

Aliyu, A. U. L. (2019). Effect of Employee Participation in Decision Making in An

Organization Performance. International Journal of Economics and Business, 3 (2), $255-259$

Cohen L, Manion L, Morrison K (2005). Research Methods in Education. $5^{\text {th }}$ Edition. New York: Routledge Farmer.

Cummings, T.G., Worley, G.W.(2009). Organization Development and Change. $9^{\text {th }}$ Edition. Mason, OH: South-Western Cengage Learning.

Deppeler J., Zay, D., Mounds, B., Gray-Beerman, M.(20I7). Inclusion through shared education. The Journal, II(I), 29-3I.

Duke, K.Z (2005). Principal's Practices Regarding Teacher Participation in School Decisionmaking. $\mathrm{PhD}$ Thesis, Unpublished. Minnesota: University of Minnesota.

Fransen, K., Mertens, N., Cotterill, S. T., Vande Broek, G., E Boen, F. (2020). From autocracy to empowerment: Teams with shared leadership perceive their coaches to be better leaders. Journal of Applied Sport Psychology, 32(I), 5-27.

Ganz, M.(20I0). Leading change: Leadership, organization, and social movements. In: Nitin Nohoria, Rakesh Khurana (Eds.): Handbook of Leadership Theory and Practice $A$ Harvard Business School Centennial Colloquim. Chapter ig.Boston, USA:Harvard Business School Publishing Corporation. 
Gulcan, G.M.(20II). Views of administrators and teachers on participation in decision making at school. Education, I3I(3), 637-652

Hallinger, P.(2004). Meeting the challenges of cultural leadership: The changing role of principals in Thailand. Discourse: Studies in the Cultural Politics of Education, $25(\mathrm{I}), 62-73$.

Kathleen, A.(2012). Mohonasen: A Blueprint for School-based Planning and Shared Decision-Making. Retrieved from https://www.mohonasen.org/wpcontent/uploads/20I4/II/Mohon_SchoolBasedPlanning_SharedDecisionMaking.pdf

Kim, S. (2002). Participative management and job satisfaction: Lessons for management leadership. Public Administration Review, 62(2), 231-24I.

Korkmaz M 2006. The relationship between organizational health and robust school vision in elementary schools. Educational Research Quarterly, 30(I): I4-I9.

Kurnia, A. S., EJabar, C. S. A. (2020). Participatory Decision-Making Style of the Principals of Vocational High School in Lembah Gumanti District West Sumatra. Jurnal Pendidikan Progresif, Io(I), ıоэ`ı6.

Heller FA., Drenth PJ., Koopman PL., Rus., V.(I983). A contingency model of participative decision-making: An analysis of 56 decisions in the three Dutch organizations. Journal of Occupational Psychology, 56, I-I8.

Lam SSL., Chen, X P., Schaubroek., J (2002). Participative decision making and employee performance in different cultures: The moderating effects of alocentrism/idiocentrism and efficay, Academy of Management, 45(5), 905-914.

Leech, D., Fulton, C.R.(2008). Faculty perceptions of shared decision making and the principal's leadership behaviors in secondary schools in a large urban district. Education, I28(4), 630

Mbatha., L, Grobler B, Loock, C.(2006). Delegation of authority by school principals - an education law perspective. Education as Change, IO(I), 3-15.

Meyer B., Meyer J., Gelzheiser, L.(200I). Observing leader roles in shared decision-making: A preliminary analysis of three teams. Journal of Educational and Psychological Consultation, I2(4), 277-312.

Mokoena, S.(20II). Participative decision-making: Perceptions of school stakeholders in South Africa. Journal of Social Sciences, 29(2), II9-I3I.

Naicker, S.R., Mestry, R (2013). Teachers' reflections on distributive leadership in primary schools in Soweto. South African Journal of Education, 33(2),I-I5.

Naidu, A., Joubert., R, Mestry., R, Mosoge, J., Ngcobo, T.(20I3). Education Management and Leadership: A South African Perspective. Cape Town: Oxford University Press

National Centre for Education Statistics,(1997). Teacher Professionalization and Teacher Commitment: A Multilevel Analyses. Washington D. C.: United States Department of Education. 
OECS Education Reform Unit,(2000). Teachers' Work and Education Reform: Research Report. St Lucia: OECS Education Reform Unit.

Patch, D. (2007). Leaders Guiding the Decision-Making Process. The Need for Understanding the Decision-Making Process. From $<$ http//www.xenos.org/essays/guiding. decisionmaking.htm $>$ (Retrieved on $\mathrm{I} 3$ May 20I9).

Patrinos, H. A., Barrera-Osorio, F., Fasih, T.(2009). Decentralized Decision-Making in Schools: The Theory and Evidence on School-based Management. The World Bank.

Republic of South Africa,(1996a). The Constitution of the Republic of South Africa, 1996. Pretoria: Government Printer.

Republic of South Africa,(1996b). Labour Relations Act, No. 66 of 1995. Pretoria:

Government Printer.

Republic of South Africa,(2005). Collective Agreement 2 of 2005. Pretoria: Government Printer.

Republic of South Africa, (20I6). Government Gazette no. 39684, Pretoria. Government Printer. Retrieved from

https://www.elrc.org.za/sites/default/files/publications/Gazette\%2039684_I22_BasicEdu.pd

Sagie, A., Elizur, D., Koslowsky., M (1995). Decision type, participative decision-making (PDM) and organizational behavior: An experimental simulation. Human Performance, 8(2), 8I-94.

Sagnak, M.(2016). Participative leadership and change-oriented, organizational citizenship: The mediating effect of intrinsic motivation. Eurasian Journal of Educational Research, 62. 199-212.

Sanyal, S., E'Hisam, M. W. (20I8). The impact of teamwork on work performance of employees: A study of faculty members in Dhofar University. IOSR Journal of Business and Management, $20(3), 15-22$.

Sergiovanni, T.J.(2005). The virtues of leadership. The Educational Forum, 69(2), II2-I23.

Somech, A.(20I0). Participative decision making in schools: A mediating-moderating analytical framework for understanding school and teacher outcomes. Educational Administration Quarterly, 46(2), I74-209.

Squelch, J.(2003). Governance of Education. In: L Lemmer (Ed.): Contemporary Education, Global Issues and Trends. Sandton: Lebone Publishing Services, pp.I27-I46.

Tschannen-Moran, M., Gareis, C.R. (20I5). Faculty trust in the principal: An essential ingredient in high-performing schools. Journal of Educational Administration, 53(I), 66-92.

Welman, J.C., Kruger, S.J (200). Research Methodology. $2^{\text {nd }}$ Edition. Cape Town: Oxford University Press.

White, C.J.(2005). Research: A Practical Guide. Pretoria: Ithuthuko Investments. 
Wu, Q., Cormican, K., छ Chen, G. (2020). A meta-analysis of shared leadership: Antecedents, consequences, and moderators. Journal of Leadership E。 Organizational Studies, $27($ I), 49-64. 